\title{
Nonverbal Cues to Deception in Title IX investigations
}

\author{
Aldert Vrij ${ }^{1}$ \\ Department of Psychology, University of Portsmouth \\ Ronald P. Fisher \\ Department of Psychology, Florida International University
}

${ }^{1}$ Correspondence concerning this article should be addressed to Aldert Vrij, Department of Psychology, University of Portsmouth, King Henry Building, King Henry 1 Street, PO1 2DY, Hants, United Kingdom. Email: aldert.vrij@port.ac.uk 


\section{Nonverbal Cues to Deception in Title IX investigations}

We applaud Meissner and Lyles' (2019) effort to point out the importance of evidence-based interviewing and lie detection in Title IX investigations. Interviewing and lie detection research focused on police interviews for a long time. A shift in focus happened after the 9/11 2001 terror attacks, which initiated research in intelligence settings (see Meissner, Surmon-Böhr, Oleszkiewicz, \& Alison, 2017, for an overview of US Government sponsored research; also see a special issue in Applied Cognitive Psychology, Granhag, Vrij, \& Meissner, 2014). There are many settings outside the criminal and intelligence domains where proper interviewing and lie detection are important, but these are typically neglected in the scientific literature. This contribution by Meissner and Lyles (2019) fills an important gap. In this contribution we focus on the deception part of their article.

Meissner and Lyles (2019) report that Title IX investigations rely entirely on voluntarily participation of interviewees. This may indirectly facilitate lie detection in that interviewers should be more likely to use an information-gathering approach than a confrontational or accusatorial approach with voluntary participants, who might terminate the interview if they found it threatening. Indeed, Meissner and Lyles (2019) report that they found no evidence that Title IX training materials advocate confrontational or accusatorial approaches. Non-judgmental information-gathering interviewing - the alternative to confrontational/accusatorial interviewing - results in an improved opportunity to distinguish between truth tellers and liars (Vrij et al., 2017). Interviewees' responses in informationgathering interviews are typically longer than those in confrontational interviews; therefore, they provide more opportunities for speech differences between truth tellers and liars to occur (Vrij, Mann, Kristen, \& Fisher, 2007; Vrij et al., 2017). In addition, the act of confrontation 
or accusation could easily have a similar emotional effect on truth tellers and liars and thereby result in similar nonverbal responses (Vrij, Hartwig, \& Granhag, 2019).

We think it is advantageous that in Title IX training not much attention seems to be paid to assessing nonverbal behaviour. Meissner and Lyles (2019) correctly point out that verbal lie detection is superior to nonverbal lie detection. This became evident in three metaanalyses. First, research examining the verbal and nonverbal responses of truth tellers and liars revealed that verbal cues are more strongly related to deception than nonverbal cues (DePaulo et al., 2003). Second, research examining people's ability to distinguish between truth tellers and liars showed higher accuracy rates when someone can only hear the target person $(63 \%)$ than when someone can only see the target person $(52 \%$, Bond \& DePaulo, 2006). Third, training people about verbal cues resulted in a medium increase in the ability to distinguish between truth tellers and liars, whereas training people about nonverbal cues resulted in only a small increase (Hauch, Sporer, Michael, \& Meissner, 2016).

The training provided to Title IX investigators, which largely neglects nonverbal lie detection, differs markedly from the training offered to criminal investigators, which is often heavily based on assessing nonverbal behaviour (Vrij \& Granhag, 2007). In lie detection based on analysing nonverbal behaviours, the concept "nervousness" is popular. A typical assumption is that liars are more nervous than truth tellers and that paying attention to nervousness enables someone to detect deceit (Vrij, Hartwig, \& Granhag, 2019). The three meta-analyses introduced above shed serious doubts on these assumptions.

We further demonstrated the limitation of a lie-detection approach based on overt signs of nervousness in a recent, unpublished, research project (Mann, Deeb, Vrij, Hope, \& Pontigia, 2019). In two experiments, participants carried out a mission involving a ferrycrossing. Half of the participants were asked to smuggle an object; the other half were nonsmugglers. The difference between Experiments 1 and 2 was that in Experiment 2, two 
confederates appeared to approach the (non)smugglers on the ferry as if looking for someone, whereas no such intervention took place in Experiment 1. Smugglers, more than nonsmugglers, in both studies reported afterwards to have felt nervous during the ferry-crossing. The secretly videotaped ferry-crossings were shown to observers, whose task was to identify the smugglers. In both lie detection studies, the observers reported relying on signs of nervousness when deciding whether participants were smuggling or not, and there were positive correlations between finding participants nervous and judging them to be smugglers. However, in Experiment 1 the smugglers and non-smugglers made an equally nervous impression on observers, whereas in Experiment 2 the non-smugglers came across as more nervous than the smugglers. In terms of lie detection, in Experiment 1 the observers' accuracy rate of correctly detecting smugglers and non-smugglers was $48 \%$ (not different from chance level, 50\%), whereas in Experiment 2 the accuracy rate was below chance level (39.2\%). The experiments highlight the problems associated with relying on nonverbal cues of nervousness when attempting to detect deceit. Liars may feel more nervous than truth tellers, but observers do not perceive them as more nervous than truth tellers. As a result, observers who detect deceit by looking for signs of nervousness perform poorly.

That smugglers made a less nervous impression than non-smugglers (Experiment 2) is probably the result of liars' behavioural control. Liars are typically more inclined than truth tellers to control their behaviour, motivated by their desire to avoid being perceived as being suspicious (Buller \&Burgoon, 1996). For example, liars, compared to truth tellers, tend to display a decrease in movements (DePaulo et al., 2003; Vrij, 2008). Possibly, the approaching confederate made both smugglers and non-smugglers more nervous, but the smugglers, more than the non-smugglers, may have tried to suppress displaying signs of nervousness. As a result, they came across as less nervous than non-smugglers. 
Based on our conversations with practitioners, it appears that interviewing is a mentally taxing task because the interviewer must listen to the interviewee's response and also think about the next question at the same time. Interviewers' cognitive load further increases if they also have to pay attention to the interviewee's behaviour (Patterson, 1995). We hypothesize therefore that paying attention to nonverbal behaviour will result in interviewers being less able to remember and report what the interviewee has said and will impair the quality of the questions they ask.

Meissner and Lyles (2019) describe good interviewing as asking further questions based on what someone initially has said ("You said the two men were arguing; could you elaborate on this?"). We agree that this approach represents good interviewing practice if the goal is to gather detailed information. We are ambivalent, however, about such a follow-up question for the purpose of detecting deception. The problem is that it gives liars a clear indication what they are expected to report (e.g., the arguing between the two men) and, since liars are likely to anticipate such a follow-up question, may provide a prepared answer that does not differ from truth-tellers' answers (Sporer \& Schwandt, 2006; Vrij, Fisher, \& Blank, 2017). The initial recall is better for lie detection purposes because it gives the respondent more latitude to answer the question however he or she wishes. Allowing respondents opportunity to answer questions strategically may differentiate between liars and truth-tellers, because liars may adopt different output strategies than truth-tellers. For instance, when given the opportunity, liars are more likely to focus on non-central elements of the event, whereas truth-tellers are more likely to describe central elements ((Leal et al., 2019; Sakrisvold, Granhag, \& MacGiolla, 2017)). Similarly, liars are more likely to provide unverifiable facts, whereas truth-tellers are more likely to provide verifiable facts (Vrij \& Nahari, 2019).

Meissner and Lyles (2019) emphasize the importance of training Title IX investigators to conduct effective interviews. Who will train these investigators? There are 
too few academic researchers who have the time or the interest to conduct such training, and experienced investigators are likely to pass along their interviewing practices, whether good or poor, to new investigators. The most practical solution is a train-the-trainer model whereby academic researchers, perhaps in concert with skilled, experienced investigators, develop training programs for Title IX investigative trainers, who can then pass along the message to the field investigators. Such a train-the-train model has been used successfully to train law enforcement investigators in the Cognitive Interview (Molinaro, Fisher, Mosser, \& Satin, 2019) and credibility assessment (Vrij, Mann, Leal, Vernham, \& Vaughan, 2016).

We agree with Meissner and Lyles (2019) that collaboration between scientists and practitioners should be encouraged. They describe their collaboration as implementing and assessing the effectiveness of evidence-based techniques in the Title IX context. We believe this is an important collaboration but also challenging: How should we measure the effectiveness of using specific lie detection methods in training or real life practice? It is a shame that Meissner and Lyles (2019) did not further discuss this important question. In addition, in the deception research domain, we are aware of more intense collaborations that have shown to be fruitful. In such collaborations, practitioners discuss with scientists real life scenarios that are challenging for them in terms of lie detection. Scientists, together with the practitioners, then try to translate those challenges into research questions, hypotheses and experimental designs. Scientists and practitioners together review the research findings and discuss how to translate them into practice. The final stage is to evaluate the efficacy of the new methods in real life settings. Meissner and Lyles' (2019) collaboration appears to focus on this final stage. 


\section{References}

Bond, C. F., \& DePaulo, B. M. (2006). Accuracy of deception judgements. Personality and Social Psychology Review, 10, 214-234. Doi: 10.1207/s15327957pspr1003_2

Buller, D. B., \& Burgoon, J. K. (1996). Interpersonal deception theory. Communication Theory, 6, 203-242. Doi: 10.1111/j.14682885.1996.tb00127.x.

DePaulo, B. M., Lindsay, J. L., Malone, B. E., Muhlenbruck, L., Charlton, K., \& Cooper, H. (2003). Cues to deception. Psychological Bulletin, 129, 74-118. Doi: 10.1037/0033-2909.129.1.74

Granhag, P. A., Vrij, A., \& Meissner, C. A. (2014). Information gathering in law enforcement and intelligence settings: Advancing theory and practice. Applied Cognitive Psychology, 28, 815816. Doi: 10.1002/acp.3093

Hauch, V., Sporer, S. L., Michael, S. W., \& Meissner, C. A. (2016). Does training improve the detection of deception? A meta-analysis. Communication Research, 43, 283-343. Doi: $10.1177 / 0093650214534974$

Leal, S., Vrij, A., Vernham, Z., Dalton, G., Jupe, L. M., Nahari, G., \&Rozmann, N. (2019). Using the model statement to elicit verbal differences between truth tellers and liars amongst Arab interviewees: a partial replication of Leal, Vrij, Deeb and Jupe (2018). Applied Cognitive Psychology.Advance online publication. Doi: 10.1002/acp.3536

Mann, S., Deeb, H., Vrij, A., Hope, L., \&Pontigia, L. (2019). Detecting smugglers:

Identifying strategies and behaviours in individuals in possession of illicit objects. Manuscript under review.

Meissner, C. A., \& Lyles, A. M. (2019). Title IX investigations: The importance of training investigators in evidence-based approaches to interviewing. Journal of Applied Research in Memory and Cognition.

Meissner, C. A., Surmon-Böhr, F., Oleszkiewicz, S., \& Alison, L. (2017). Developing an evidencebased perspective on interrogation: A review of the U.S. Government's High-Value Detainee 
Interrogation Group Research Program. Psychology Public Policy and Law, 23, 438-457.

Doi: $10.1037 /$ law0000136

Molinaro, P.F., Fisher, R. P., Mosser, A.E., \& Satin, G.E. (2019). Train-the-trainer: Methodology to learn the cognitive interview. Journal of Investigative Psychology and Offender Profiling, 6, 32-43. Doi: 10.1002/jip.1518

Patterson, M. L. (1995). Invited article: A parallel process model of nonverbal communication. Journal of Nonverbal Behavior, 19, 3-29. Doi: 10.1007/BF02173410

Sakrisvold, M. L., Granhag, P. A., \& Mac Giolla, E. (2017). Partners under pressure: Examining the consistency of true and false alibi statements. Behavioral Sciences \& the Law, 35, 75-90.

Doi: $10.1002 / \mathrm{bs} 1.2275$

Sporer, S. L., \& Schwandt, B. (2006). Paraverbal indicators of deception: A meta-analytic synthesis. Applied Cognitive Psychology, 20, 421-446. Doi: 10.1002/acp.1190

Vrij, A. (2008). Detecting lies and deceit: Pitfalls and opportunities, second edition. Chichester: John Wiley and Sons.

Vrij, A., Fisher, R., Blank, H. (2017). A cognitive approach to lie detection: A meta-analysis. Legal and Criminological Psychology, 22, 1-21. Doi: 10.1111/lcrp.12088

Vrij, A., \& Granhag, P. A. (2007). Interviewing to detect deception. In S. A. Christianson (Ed.), Offenders' memories of violent crimes (pp. 279-304). Chichester, England: John Wiley \& Sons, Ltd.

Vrij, A., Hartwig, M., \& Granhag, P. A. (2019). Reading lies: Nonverbal communication and deception. Annual Review of Psychology, 70, 295-317. Doi: 10.1146/annurev-psych-010418103135

Vrij, A., Mann, S., Kristen, S., \& Fisher, R. (2007). Cues to deception and ability to detect lies as a function of police interview styles. Law and Human Behavior, 31, 499-518. Doi: 10.1007/s10979-006-9066-4 
Vrij, A., Mann, S., Leal, S., Vernham, A., \& Vaughan, M. (2016). Train-the-trainers: A first step towards a science-based cognitive lie detection training workshop delivered by a practitioner. Journal of Investigative Psychology and Offender Profiling, 13, 110-130. Doi: 10.1002/jip.1443

Vrij, A., Meissner, C. A, Fisher, R. P., Kassin, S. M., Morgan III, A., \& Kleinman, S. (2017). Psychological perspectives on interrogation. Perspectives on Psychological Science, 12, 927955. Doi: $10.1177 / 1745691617706515$

Vrij, A. \&Nahari, G. (2019). The Verifiability Approach In J. J. Dickinson, N. Schreiber Compo, R. N. Carol, B. L. Schwartz, \& M. R. McCauley (eds.) Evidence-Based Investigative Interviewing(pp. 116-133). New York, U.S.A.: Routledge Press. 